appraisal of the situation ; when a junior brought him a problem, he would say, "and what do you recommend ?" It is no wonder that he was much loved and respected by his staff. A. C. Menzies

\section{Prof. Thomas Thomson}

WrTH the recent death of Prof. T. Thomson we saw the passing of a person who, with singular devotion, had spent his whole life in the service of one educational institution.

When Thomson, a Londoner, entered the University College of North Wales, Bangor, in the first decade of this century, he was somewhat older than the average run of students at the time, and after reading for honours in chemistry, and taking a first, he continued to read forestry under Prof. Fraser Story, then head of that Department.

During the First World War, Story was called to London, and Thomson worked in Wales on problems of woodland felling and timber supplies. This gave him an admirable introduction to the Welsh countryside and to the mind of the countryman, a most valuable asset early in a professional career.

In 1919, the Forestry Commission was set up. Story stayed on in London as its education officer and Thomson returned to Bangor to take charge of the Forestry Department, first as an independent lecturer and latterly, before his retirement, eleven years or so ago, as professor. This was a period of expansion and adaptation in the subject, to meet the new and expanding economy of the new State forest policy in Britain, together with the continuance of training of forest officers for work in the Dominions and overseas.

It was also the period of transfer of activities from the Old Buildings in the Penrhyn Arms Hotel to the Memorial Buildings in Deiniol Road in the midtwenties. It also witnessed the ever-expanding provision of field courses of training, extramural to the Department at Bangor. Before the War there had been established at Penisa'r Glyn near Chirk in the Ceiriog Valley, Denbighshire, an experimental forestry unit, in the layout of which Thomson was the prime mover. Now, after the War, there followed comprehensive and extensive practical forestry courses in the field in the French State forests, with their long established and tested traditions. This was eventually extended to embrace collateral courses in the newer State forests of Britain, as these developed and matured.

As an academic discipline the subject suffered severely at this time from the serious lack of authoritative standard text-books in English. This Prof. Thomson set himself to remedy, and in due course appeared his English translation of the classic text of "The Foundations of Silviculture" from the German of Busgen and Munch. This was followed by Thomson's own "Outline of Forestry", less arnbitious in scope, but withal a very worthy students' manual.

During the Second World War, and the second severe onset on the native timber resources of Britain in one short generation, Thomson gave admirable service, outside his Department, in operating the State scheme of grants for new planting and replanting of timber trees. His thorough and extensive knowledge of conditions in the field in Wales, based on his initial experience during the First World War and extended since, and his natural endowments in the field of human relationship made him a first-rate agent in working this policy-indeed a very successful ambassador among estate and woodland owners.

He had retired from the chair before the Department made its second move to the present site at the corner of Deiniol Road and Glanrafon Hill, but it gladdened his heart to see, so firmly established and so full of promise to the future, a pulsating and virile school that he had done so much to bring into being and to support in its infancy.

Prof. Thomson served his College well in the field of internal administration - a field of service he rather delighted in-as curator of the College grounds, in Board of Faculty, in Senate and as Dean. He was never forward in the rough and tumble of argument and advocacy in the early stages of discussion of any issue, but invariably he came in towards the end with words of wisdom and sagacity. He was a very sound dialectician, a loyal colleague and a sturdy pillar of the Old Students' Association of the College.

Prof. Thomson was twice married, first to Miss Gwen Phillips, eldest daughter of the late Reginald W. Phillips, first professor of botany in the College, and secondly to Miss Connie Izard, a member of the College Music Trio, who survives him.

\section{R. Alun Roberts}

\section{Mr. Cyril Barnard}

Mr. Cyril Cuthbert Barnard, librarian of the London School of Hygiene and Tropical Medicine, and author of the Barnard system of classification for medical libraries, was killed in a road accident on March 6. Son of Harry Barnard, an artist specializing in the design of Wedgwood ware, he was born at St. Margaret's, Middlesex, on July 23, 1894, and was educated at the Stationers' Company School and at the London School of Economics. In 1914, he became a library assistant at the Royal Society of Medicine and in 1918 assistant librarian at the Wellcome Historical Medical Library. During 192128 he served as librarian of the Tropical Diseases Library, and in 1929 took charge of the library of the London School of Hygiene and Tropical Medicine in its new building in Keppel Street.

Mr. Barnard graduated B.A. (London) with honours in 1922, and two years later obtained the diploma of the School of Librarianship. In 1931, he was awarded the honours diploma of the Library Association for a thesis entitled "A Classification for Medical Libraries", which was published in 1936. A second enlarged edition, "A Classification for Medical and Veterinary Libraries", came out in 1955. Mr. Barnard was elected a Fellow of the Library Association in 1925, served on the Council of the Association and as secretary of its University and Research Section, and in 1947 became chairman of the newly created Medical Section. In 1953, he was joint honorary secretary of the First International Congress on Medical Librarianship held in London. In 1952, he was invited by the World Health Organization to reclassify its library at Geneva according to his system. At his own library, which his expert knowledge and his devotion made one of the finest of its kind in the world, he introduced special courses of instruction in the use of the library for students.

A member of the Society of Friends, linguist, historian, and a friendly, cheerful, approachable, and quietly firm personality, Mr. Barnard will be greatly missed in medical library circles. 